THUFULI: Jurnal Pendidikan Islam Anak Usia Dini

Volume 3 Nomor 1 Tahun 2021

e-ISSN: $\underline{2685161 X}$

\title{
PENGARUH PERMAINAN ENGKLEK PESAWAT TERHADAP KEMAMPUANMOTORIK KASAR ANAK KELAS B DI NGANJUK
}

\author{
Shinta Nur Azizah Rohmah ${ }^{1}$, Sri Setyowati ${ }^{2}$ \\ Universitas Negeri Surabaya \\ e-mail: ${ }^{1}$ shinta.17010684020@mhs.unesa.ac.id, ${ }^{2}$ srisetyowati@unesa.ac.id
}

Diterima: 5 April $2021 \quad$ I Direvisi: 7 Mei $2021 \quad$ I Disetujui: 9 Mei 2021

(C)2021 Pendidikan Guru Raudhatul Atfhal Fakultas Agama Islam Universitas Islam Malang

\begin{abstract}
The purpose of this study was to determine the effect of the plane crank game on children's gross motor skills using a quasi experimental method. The population in this study were class B teachers in Kindergarten Pertiwi, Pace District, Nganjuk. Collecting data using a questionnaire technique with google form media. Analysis of research data using validity test, reliability test and regression statistical analysis. This study shows that teachers gave Aircraft Engklek games 3-5 times. In the plane crank game variable, there is an average pre-test score of 16.7 and a post-test scoreof 35.5. While the gross motor skills variable pre-test mean score was 17.3 and the post-test mean score was 35.3. Thus, the increase in gross motor skills of children is influenced by the movement of jumping with one leg with a presentation value of $49 \%$, jumping on two legs by $20 \%$ and jumping in the box without falling by 31\%. Based on the results of data analysis using SPSS 20 with a significance level of 0.05, the value was 0.034 or less than 0.05. From these results it can be concluded that the Aircraft Engklek game affects the gross motor skills of $B$ grade children in Nganjuk.
\end{abstract}

Kata unci: game, plane crank, gross motor skills

\section{A. Pendahuluan}

Usia 0-6 tahun merupakan tahapan usia yang ada pada masa peka atau bisa disebut juga dengan masa keemasan (golden age), pada masa-masa tersebut merupakan dasar pertama untuk menstimulasi perkembangan kognitif, sosial emosional, bahsa, motorik, serta moral agama. Secara tidak langsung aik disengaja maupun tidak disengaja lingkungan akan mengirimkan berbagai stimulus serta upaya yang akan diterima anak. Kartini (2013), yang menyatakan bahwa usia TK adalah usia golden age (usia emas) karena seluruh aspek perkembangannya telah siap untuk dikembangkan dengan berbagai stimulus kegiatan. Aspek perkembang-an tersebut meliputi nilai agama dan moral, bahasa, fisik motorik, seni dan kognitif yang saling terkait karena pembelajaran di TK menggunakan 
tematik terpadu.

Anak akan mulai peka terhadap hal-hal sekitar (Montessori). Pada masa ini, anak berpotensi secara besar untuk memaksimalkan segala aspek perkembangan dan kemampuannya termasuk perkembangan motorik, namun pada kenyataannya beberapa sekolah kurang memaksimalkan strimulus pada kemampuan motorik kasar anak. Kegiatan yang dilakukannya pun tidak bervariasi dan umumnya kegiatan untuk menstimulus kemampuan motorik kasar adalah melakukan senam yang beberapa anak tidak mengikuti gerakan senam. Melakukan permainan dapat menjadi solusi dan menarik perhatian anak karena menyenangkan.

Menurut Sulyandari (2020) Motorik adalah dasar dari gerak yang harus distimulus karena berkurangnya lahan untuk bergerak. Anak membutuhkan kepuasan kinestetik, sehingga ia akan bergerak bebas dan tak bisa diam. Hal ini sejalan dengan Hurlock (2013) yang menyatakan bahwa, kemampuan motorik kasar adalah suatu pengendalian gerakan anggota badan dengan melakukan kegiatan secara sinkron antara tatanan saraf, otot, dan otak, serta spinal cord, ialah kemampuan yang dibutuhkan seorang balita untuk mendukung tumbuh kembang mereka. Oleh karena itu, perkembangan motorik ini merupakan salah satu hal yang sangat penting.

Gordon (1985), yang menyatakan bahwa perkembangan fisik motorik kasar pada anak akan terstimulus selama anak -anak bergerak, dan akan mencapai kesempurnaan pada usia 6 tahun sampai 7 tahun. Selama rentang waktu tersebut, penting untuk memperhatikan stimulus yang dilakukan terhadap anak.

Berdasarkan uraian tersebut, maka dapat dikatakan motorik kasar merupakan suatu ketrampilan yang gerak dasarnya dibantu oleh otot-ototbesar. Gerak motorik dasar misalnya melompat, berlari, menendang dan sebagainnya yang membutuhkan keseimbangan, ketangkasan serta kelincahan.

Banyak faktor lingkungan telah berpengaruh terhadap pemulihan keterampilan motorik awal. Oleh karena itu, latihan serta panduan terstruktur tetap harus disediakan sejak taman kanak-kanak hingga tingkat sekolah menengah. Menurut Soetjiningsih (2012), sejumlah faktor penyebab perkembangan motorik kasar serta tumbuh dan kembang pada anak adalah: 1) faktor genetik, bisa dikatakan sebagai pondasi agar tumbuh kembang sehingga dapat mendapatkan goals yang diharapkan. 2) faktor lingkungan, adalah salah satu

Thufuli: Volume 3 Nomor 1, Tahun 2021 
faktor amat penting untuk mengembangkan motorik serta tumbuh kembang pada anak. Lingkungan ini adalah salah satu hal penting bagi berhasil tidaknya potensi bawaan anak.

Telah banyak cara yang dapat dipakai dalam menstimulus kemampuan motorik kasar anak diantaranya bermainan permainan tradisional. Piaget mengatakan bahwa bermain merupakan kegiatan berulang-ulang yang membuat seseorang senang atau puas (Apriani, 2013).

Permainan tradisional adalah salah satunya. Permainan ini dahulu sering dimainkan anak-anak dan telah berkembang dari waktu ke waktu. Biasanya dalam permainan tersebut mengandung nilai- nilai budaya bangsa. Seiring dengan berkembangnya jaman, semakin lama permainan tradisional mulai dilupakan secara perlahan, karena beragamnya permainan modern, terutama di daerah perkotaan. Keberadaan permainan tradisional mulai tergantikan denganadanya televisi dan gadged, sehingga makin sedikit anak-anak yang melakukan permainan tradisional. Hal ini menyebabkan kreativitas anak berkurang, padahal gerakangerakan pada saat anak-anak bermain permainan tradisional mempunyai dampak serta manfaat bagi perkembangan motorik kasar anak.

Dari hasil observasi di beberapa TK di Nganjuk pada bulan Februari 2020, secara aris besar menunjukkan bahwa kemampuan motorik kasar ana belum mencapai perkembangan yang telah ditentukan oleh Permen Diknas seperti: 1) menirukan gerakan tubuh yang terkoordinir untuk melatih kelenturan. 2) keseimbangan, yaitu dengan berjalan jinjit secara seimbang sehingga hasilnya masih belum sesuai dengan tingkat pencapaian pertimbangan yang telah ditetapkan. 3) berjalan ke samping tanpa membalik badan, 4) berlari sambil melompat tanpa terjatuh, 5) melompat dengan satu kaki.

Belum sesuainya perkembangan kemampuan motorik ini disimpulkan peneliti saat mengamati beberapa anak yang masih belum bisa seimbang dan belum bisa melompat dengan satu kaki. Berdasarkan latar belakang diatas, tujuan penelitian ini adalah untuk mengkaji pengaruh engklek pesawat terhadap kemampuan motorik kasar anak kelas B di Nganjuk.

Dari hal tersebut di atas, maka peneliti mengambil langkah dengan menyetimulus anak-anak menggunakan engklek, karena dirasa sangat cocok untuk memberikan stimulus motorik kasar. Apriani (2013) mengungkapkan bahwa, "Engklek pesawat merupakan permainan yang dimainkan dengan 
melakukan lompatan-lompatan pada suatu bidang datar. Biasanya dilakukan di atas permukaan tanah yang telah tergambar kotak-kotak. Lalu pemain akan melompati kotak satu ke kotak lainnya memakai satu kaki."

Berdasarkan penjelasan tersebut, maka engklek pesawat merupakan suatu permainan dimana pemain meloncati kotak dengan satu kaki atau persegi yang berbentuk seperti pesawat menggunakan satu kaki, yang dapat dilakukan di tanah lapang atau pekarangan dengan tempat yang datar.

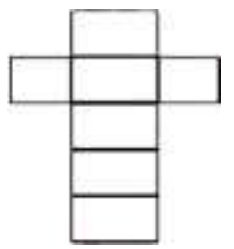

\section{Gambar 1. Engklek pesawat}

\section{B. Metode}

Pengumpulan data penelitian menggunakan teknik kuisioner/angket. yang dilakukan dengan memberikan kuisioner berupa google form, dimana pada google form tersebut akan terlampirkan video dan foto permainan engklek pesawat. Menurut Hartono (2013) jika peneliti mengetahui variabel yang akan diukur dan harapan responden dengan pasti, maka angket merupakan teknik pengumpulan data yang efektif, dan angket dianggap sebagai teknik pengumpulan data yang efektif. Instrumen penelitian yang digunakan ialah check list dengan penilaian memakai kriteria sebagai berikut: 1) Berkembang Sangat Baik (BSB), 2) Berkembang Sesuai Harapan (BSH), 3) Mulai Berkembang (MB), 4) Belum Berkembang (BB).

Analisis data menggunakan uji validitas, uji reliabilitas dan analisa statistik regresi. Uji validitas digunakan untuk mengukur valid tidaknya suatu kuesioner atau menguji apakah kuesioner dapat mengukur tingkat yang ingin diukur peneliti. Ketentuan uji validitas menurut Sugiyono (2016), yaitu apabila diperoleh nilai r-hitung $>0,3$ maka kuesioner dinyatakan valid. Person product moment (r) dipakai untuk mengukur derajat hubungan antara dua variabel.

Menurut Hartono (2013) reliabilitas sebagai konsep pengukuran menunjukkan kestabilan dan konsistensi instrumen dan dapat digunakan untuk memperoleh keunggulan instrumen. Pada penelitian ini, uji reliabilitas dipakai untuk 
mengetahui konsistensi responden saat menjawab pertanyaan dalam kuesioner. Menurut Kadir (2015) rumus yang digunakan dalam pengujian adalah Cronbach Alpha. Instrumen kuesioner dikatakan reliabel apabila nilai koefisiennya lebih besar dari atau sama dengan 0,6.

Analisis statistik regresi linier sederhana menggunakns Uji t dilakukan untuk mengetahui apakah variabel bebas yaitu, permainan engklek pesawat berpengaruh terhadap variabel kemampuan motorik kasar anak (Y). Kriteria uji t adalah menggunakan signifikansi 0,05 dengan ketentuan:

a. Ha : diterima, jika nilai signifikansi < 0,05 maka Terdapat pengaruh permainan engklek pesawat terhadap kemampuan motorik kasar anak kelas B di Nganjuk.

b. H0 : ditolak, jika nilai signifikansi > 0,05 maka Tidak terdapat pengaruh permainan engklek pesawat terhadap kemampuan motorik kasar anak kelas B di Nganjuk Selain dengan rumus manual, penyelesaian uji reliabilitas, validitas dananalisis statistik regresi linier sederhana ini bisa menggunakan SPSS Statistics 20.

\section{Hasil dan Pembahasan}

TK Pertiwi di Kecamatan Pace merupakan salah satu pendidikan formal yang berada di Kecamatan Pace Kabupaten Nganjuk sejumlah 28 TK yang masingmasing guru kelas B rata-rata memberikan satu responden atau satu anak untuk menerapkan permainan tradisional Engklek Pesawat dan terdapat 2 TK yang memberikan hasil sebanyak 2 anak. Proses pengambilan data dilangsungkan dalam kurun waktu 2 bulan, dimulai dari bulan desember 2020 sampai Februari 2021.

Hasil eskperimen yang telah dilakukan di TK Pertiwi Kecamatan Pace dijelaskan menurut hasil analisis instrumen lembar pengamatan (berupa google form). Analisis data meliputi gejala umum kemampuan motorik kasar. Selain itu, data pre-test dan post-test juga akan dibandingkan serta dianalisis. Kemudian dilanjutkan dengan menganalisis secara statistik 10 pertanyaan untuk permainan Engklek Pesawat dan 10 butir pertanyaan untukkemampuan motorik kasar.

Perhitungan uji validitas ini menggunakan SPSS 20 menunjukkan bahwa masing-masing indikator kemampuan motorik kasar pada pertanyaan permainan Engklek Pesawat kuesioner memiliki nilai $r$ diatas $(0,361)$ sehinggamasing no item

Thufuli: Volume 3 Nomor 1, Tahun 2021 
Shinta Nur Azizah Rohmah ${ }^{1}$, Sri Setyowati ${ }^{2}$

pertanyaan dan setiap indikator dinyatakan valid.

Adapun hasil uji reliabilitas penelitian digambarkan pada tabel sebagai berikut:

Tabel 1. Uji Realiabilitas

\begin{tabular}{|l|l|l|}
\hline Variabel & $\begin{array}{l}\text { Koefisien } \\
\text { cronbach's alpha }\end{array}$ & Keputusan \\
\hline Permainan Engklek Pesawat & 0,918 & Reliabel \\
\hline Kemampuan Motorik Kasar & 0,918 & Reliabel \\
\hline
\end{tabular}

Dari tabel tersebut, diperoleh nilai koefisien cronbach's alpha permainan Engklek Pesawat dan kemampuan motorik kasar berada di atas 0,6 dengan interpretasi sedang. Hasil reliabilitas yang berada di kisaran 0,90-1,00 ini menunjukkan bahwa kuesioner terbukti memiliki tingkat reliabelitas yang tinggi. Selanjutnya, untuk mengetahui berpengaruh tidaknya engklek pesawat terhadap kemampuan motorik kasar anak kelas B, dilakukan uji hipotesis sebagai berikut:

Tabel 2. Tabel Hasil Uji Regresi Linier Sederhana

\begin{tabular}{|l|l|l|l|l|l|}
\hline Model & Sum of squares & $d f$ & Mean square & $F$ & Sig. \\
\hline Regression & 78,457 & 1 & 78,457 & 4,964 &, $034^{\mathrm{b}}$ \\
Residual & 442,510 & 28 & 15,804 & & \\
Total & 520,967 & 29 & & & \\
\hline
\end{tabular}

Berdasarkan tabel di atas nilai signifikan sebesar 0,034 atau kurang dari 0,05 atau $\mathrm{H}_{0}$ ditolak. Sehingga dapat dinyatakan bahwa engklek pesawat berpengaruh terhadap kemampuan motorik kasar anak kelas B di Nganjuk.

Diagram 1. Hasil pre-test dan post-test permainan engklek pesawat

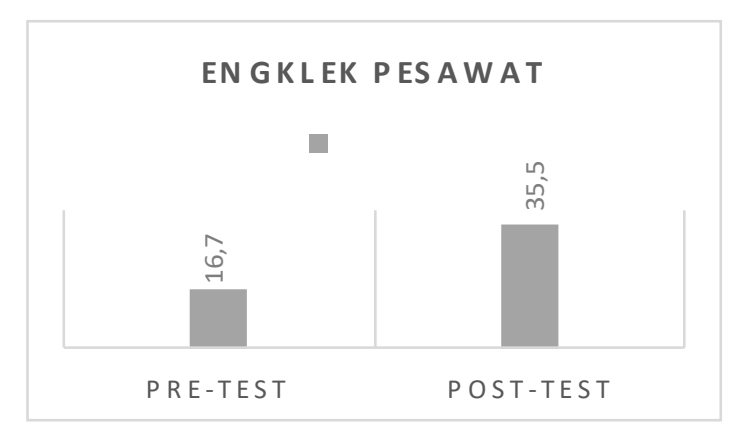

Dari diagram 1 menunjukkan bahwa hasil dari nilai pre-test dan post-test

Thufuli: Volume 3 Nomor 1, Tahun 2021 
Shinta Nur Azizah Rohmah ${ }^{1}$, Sri Setyowati ${ }^{2}$

pada permainan engklek pesawat terlihat perbandingan nilai yang signifikan antara sebelum dan saat dilakukannya experimen, yaitu pada pre-test menunjukkan 16,7 untuk nilai rata-rata. Sedangkan untuk post-test menunjukkan 35,5 untuk nilai rata-rata permainan engklek pesawat.

\section{Diagram 2. Hasil pre-test dan post-test kemampuan motorik kasar}



Dari diagram di atas menjelaskan bahwa hasil dari nilai pre-test dan posttest pada kemampuan motorik kasar terlihat perbedaan nilai yang signifikan antara sebelum dan saat dilakukannya experimen, yaitu pada pre-test menunjukkan 17,3 untuk nilai rata-rata. Sedangkan untuk post-test menunjukkan 35,3 untuk nilai rata-rata kemampuan motorik kasar.

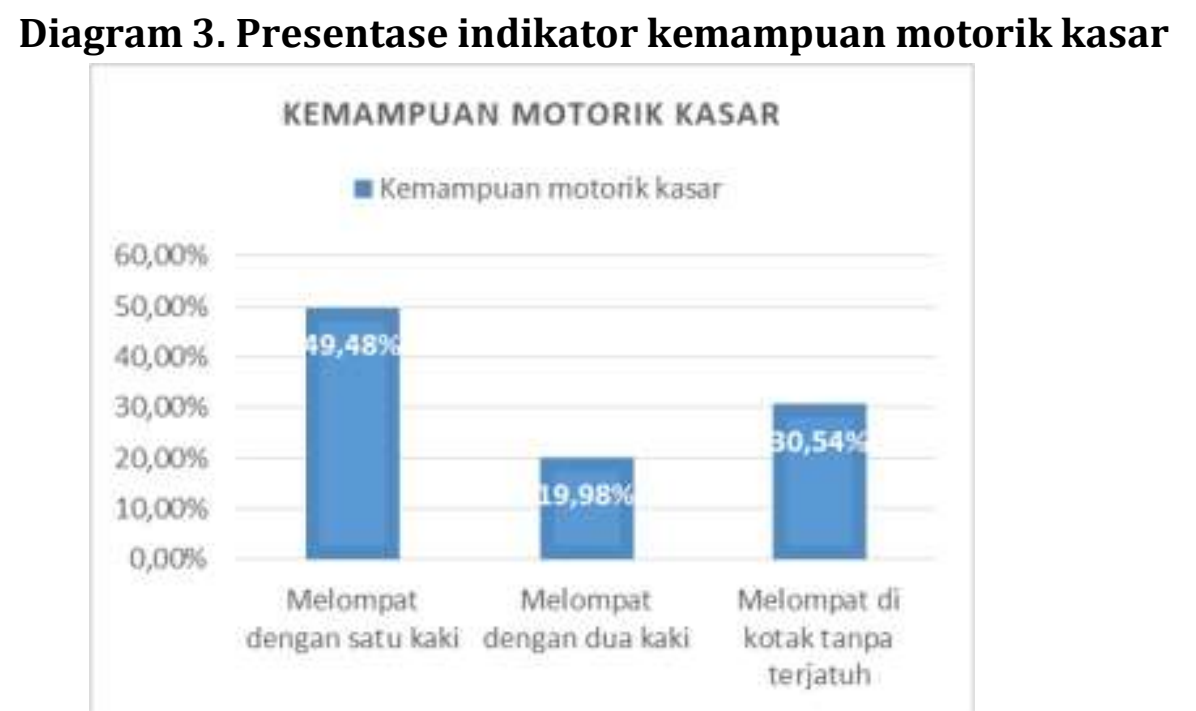

Dari diagram di atas menunjukkan bahwa setelah anak melakukan

Thufuli: Volume 3 Nomor 1, Tahun 2021 
permainan engklek pesawat, anak mengalami peningkatan kemampuan motorik kasar pada indikator kemampuan melompat anak menggunakan satu kaki mempunyai skor presentasi paling besar yaitu 49\%. Diurutan kedua kemampuan melompat di kotak tanpa terjatuh sebesar 31\%, dan diurutan terakhir yaitu melompat dengan dua kaki sebesar $20 \%$.

Penelitian yang dilakukan di TK Pertiwi Kecamatan Pace Kabupaten Nganjuk sebanyak 28 Taman Kanak-kanak dengan 1-2 responden kelas B pada masing-masing TK dengan pengambilan data menggunakan google form.

Rata-rata guru memberikan permainan kepada anak sebayak 3-5 kali permainan Engklek Pesawat. Permainan Engklek Pesawat dapat menstimulus kemampuan motorik kasar anak dikarenakan pada permainan EngklekPesawat dikendalikan dengan gerakan tubuh yang terkoordininasi antara otot anak. Saat anak melakukan permainan engklek pesawat, mereka menggunakan kaki untuk melompat dan koordinasi tangan saat melempar gaco, hal tersebut mendukung teori yang dikemukakan oleh Hurlock (2013). Hurlock menyebutkan bahwa kemampuan motorik kasar ini dapat dikatakan sebagai aktivitas pengendalian pada gerakan tubuh dengan manjalani kegiatan-kegiatan yang terkoordinir.

Banyak faktor yang dapat memberikan dapak pada kemampuan motorik kasar, salah satunya adalah faktor lingkungan dan permainan engklek pesawat yang merupakan warisan dari nenek moyang atau bisa disebut sebagai permainan tradisional, yang berarti bahwa permainan engklek merupakan bagian dari warisan ras/suku bangsa. Perubahan kemampaun motorik kasar anak mengalami peningkatan dikarenakan terdapat stimulasi dari lingkungan yaitu stimulus berupa permainan Engklek Pesawat. Perubahan kemampaun tersebut membuktikan pendapat yang telah dipaparkan oleh Soetjiningsih (2012) menguraikan bahwa komponen utama yang bisa berdampak kepada peningkatan motorik anak adalah lingkungan.

Hasil pre-test dan post-tes di TK Pertiwi di Kecamatan Pace Kabupaten Nganjuk menunjukkan bahwa:

1. Masing-masing indikator berada pada kategori sedang.

2. Setelah anak-anak kelas B melakukan post-test menggunakan permainan Engklek Pesawat, kemampuan motorik kasar bertambah signifikan serta berada di kriteria tinggi.

Anak bermain untuk menghabiskan waktu luang dan berkumpul bersama

Thufuli: Volume 3 Nomor 1, Tahun 2021 
teman untuk mengisi waktu luangnya. Selain menjaga kesehatan, padadasarnya saat memainkan permainan engklek ini merupakan salah satu pendekatan terbaik dalam memperbaiki dan menumbuhkan kemampuan kognitif dan motorik anak. Harapannya, kemampuan motorik kasar anak akan sesuai dengan kompetensi yang tertuang dalam kurikulum PAUD 2013.

Peningkatan yang signifikan pada pre-test dan pot-test terhadap kemampuan motorik kasar anak mendukung penyataan dari Trost (dalam Puspita dkk, 2018). Pada jurnalnya yang berjudul Interverensi Untuk Mempromosikan Aktifitas Fisik Pada Anak Kecil, dijelaskan bahwa penting untuk memberikan stimulasi anak karena akan turut serta untuk meningkatkan perkembangan motorik pada anak, terutama pada usia dini.

Aktivitas bermainmembuat seorang anak akan berusaha untuk mendapatkaan dan mengolah suatu informasi. Anak juga akan mempelajari halhal baru di sekitarnya sehingga melatih ketrampilan yang dimiliki si anak. Menurut Ginsburg (2007) aktivitas yang dilakukan melalui bermain sangat penting untuk perkembangan anak, karena aspek perkembangan lainnya akan ikut terstimulus. Das (2017) juga mengungkapkan bahwa permainan bebas dan permainan terbimbing adalah pembelajaran yang menyenangkan, bermain adalah belajar dengan cara yang menyenangkan dan kaya secara konsep, bahkan penelitian terkini mengungkapkan dasar biologis manusia adalah bermain.

Pada saat anak melakukan permainan engklek pesawat, tidak disadari bahwa anak melatih kemampuan motorik kasarnya. Hal tersebut dibuktikan dengan pada indakor keseimbangan yang merupakan unsur-unsur dari motorik kasar dengan rata-rata pre-test sebesar 17,3. Sementara untuk post- test adalah 35,3. Peningkatan rata-rata pre-test dan post-test pada keseimbangan anak membenarkan pendapat Harold dan Rosemary (dalam Fatmawati, 2016) yang menyatakan bahwa "Unsur-unsur yang ada pada motorik kekuatan, kecepatan, ketahanan, keseimbangan, fleksibilitas, dan koordinasi."

Pada indikator gerakan melompat anak mengalami peningkatan yang signifikan dengan nilai rata-rata pre-test 1,8 dan nilai rata-rata post-test 3,7 dan melempar anak mengalami perkembangan kemampuan yang signifikan dengan nilai rata-rata pre-test 1,5 dan nilai rata-rata post-test 3,4 . Sehingga pada variabel permainan engklek pesawat terdapat nilai rata-rata pre-test 16,7 dan nilai posttest 35,5 dimana anak mampu melompat dengan satu kaki maupun dua kaki serta dapat melempar gaco dengan tubuh yang tegap dan tepat pada kotak Engklek

Thufuli: Volume 3 Nomor 1, Tahun 2021 
Pesawat.

Anak sudah mampu mengkoordinasikan mata dan tangan serta gaco yang dilempar ke kotak Engklek. Gerakan melompat pada permainan engklek pesawat yang dimainkan oleh anak kelas B di TK Pertiwi Kecamatan Pace mengalami peningkatkan yang signifikan antara pre-test dan post-test, yang berarti permainan engklek pesawat dapat meningkatkan kemampaun koordinasi gerakan secara keseluruhan.

Berdasarkan hasil penelitian secara keseluruhan, penelitian ini membuktikan bahwa permainan tradisional engklek pesawat memiliki pengaruh secara positif untuk meningkatkan kemampuan motorik kasar anak kelas B. Nilai signifikansi uji t hasil perhitungan SPSS 20.0 adalah sebesar 0,034 sehingga kurang dari 0,05. Berarti hipotesis diterima sehingga permainan engklek pesawat memiliki pengaruh terhadap kemampuan motorik kasar anak kelas B di Nganjuk.

Bermain engklek akan menyetimulus perkembangan ketrampilan motorik kasar anak tersebut. Diterimanya hipotesis penelitian ini juga didukung dengan data penelitian yang memperlihatkan adanya peningkatan kemampuan motorik kasar anak setelah melaksanakan kegiatan permainan engklek pesawat. Diperoleh nilai rata-rata keseluruhan yaitu 17,3 saat sebelum dilaksanakannya uji coba permainan engklek pesawat, sedangkan untuk post-test didapatkan nilai 35,3. Angka-angka tersebut telah membuktikan bahwa terdapat peningkatan nilai rata-rata kemampuan motorik anak sebelum dan sesudah menggunakan permainan engklek pesawat. Maka dalam mengembangkan kemampuan motorik kasar diharapkan guru dapat memberikan permainan engklek pesawat setidaknya seminggu satu kali.

Permainan ini membantu stimulus motorik kasar dan mengoptimalisasi kemampuan melompat anak yang merupakan salah satu aspek pada kemampuan motorik kasar. Menurut Santrock (2012) kemapuan fisik motorik kasar sangat berpengaruh pada aktivitas sehari-hari. Kemampuan tersebut harus distimulus, karena keterampilan gerak dasar seperti gerak lokomotor, non lokomotif, dan gerak manipulatif digunakan sebagai landasan perkembangan keterampilan motorik kasar anak dapat berkembang dengan stimulus yang baik. Gerak lokomotor adalah gerakan yang membutuhkan pindah tempat saat tubuh bergerak. Gerak non-lokomotor adalah gerak yang dilakukan di tempat tanpa bergerak pindah. Sedangkan aktivitas sehari-hari membutuhkan koordinasi dari 
dua gerakan tersebut, tanpa latihan dan stimulus yang baik, anak tidak akan berkembang motorik kasarnya dengan optimal. Santrock juga berpendapat bahwa, pertumbuhan anak diikuti oleh pertumbuhan otak, karena koordinasi antara otot dan otak saling terjadi dan hal itulah yang dinamakan dengan sensasi. Sehingga permainan ini sangat membantu perkembangan fisik motorik anak.

\section{Simpulan}

Berdasarkan uraian di atas dapat disumpulakan bahwa hasil penelitian yang telah dilaksanakan di TK Pertiwi Kecamatan Pace Kabupaten Nganjuk disimpulkan bahwa banyak cara untuk mengembangkan kemampuan motorik kasar sosial anak. Salah satunya dengan menggunakan permainan tradisional Engklek Pesawat. Selain tidak mengeluarkan biaya yang banyak, permainan tradisional dinilai efektif untuk mengembangkan berbagai macam aspek salah satunya adalah kemampuan motorik kasar anak.

Pada penelitian di TK Pertiwi Kecamatan Pace Kabupaten Nganjuk kali ini, dapat dibuktikan bahwa permainan Engklek Pesawat berpengaruh terhadap kemampuan motorik kasar anak melalui observasi menggunakan google form dan hasil pengolahan data.

\section{Daftar Rujukan}

Apriani. (2013). Penerapan Permainan Tradisional Engklek untuk Meningkatkan Kemampuan Motorik Kasar Anak Kelompok B RA Al Hidayah 2 Tarik Sidoarjo. PAUD Teratai, 2(1),

Das, Brenna Hassainger, Kathy Hirsh-Pasek, Roberta Michnick Golinkoff. (2017). The Case of Brain Science and Guided Play: A Developing Story. Journal NAEYC. (online) Vol. 72, (2) (https://www.naeyc.org/resources/ pubs/yc/may2017/case-brain-science-guided-play) diakses tanggal 6 Juni 2021

Ginsburg, K. R., Shifrin, D. L., Broughton, D. D., Dreyer, B. P., Milteer, R. M., Mulligan, D. A., ... Smith, K. (2007). The importance of play in promoting healthy child development and maintaining strong parent-child bonds. Journal of Pediatrics. (Online) 119(1), 182-191 (https://doi.org/10.1542/peds.20062697). diakses tanggal 27 Maret 2021

Gordon, Ann Miles dan Gordon Williams Browne. (2011). Beginnings and Beyond. Foundations in Early Childhood Education. America: Delmar Publishers inc. 
Shinta Nur Azizah Rohmah ${ }^{1}$, Sri Setyowati ${ }^{2}$

Hartono. (2013). Metode Penelitian Bisnis. Yogyakarta: BPFE.

Hurlock, B Elizabeth. (2013). Perkembangan Anak. Jakarta; Erlangga

Kadir. (2015). Statistika Terapan: Konsep, Contoh dan Analisis Data dengan Program SPSS/Lisrel dalam Penelitian. Jakarta: Rajawali.

Kartini, Novalia. (2013). Penerapan Model Pembelajaran Numbered of Head Judul Toghether "Kepala Bernomor" untuk Meningkatkan Kemampuan Kognitif Anak Kelompok B di TK ABA 24 Malang. Jurnal Ilmiah PAUD, 1 (1): halaman 26

Montessori, Maria. Tanpa Tahun. Metode Montesori. Terjemah Gutex, Gerald Lee. 2013. Yogyakarta: Pustaka Pelajar.

Puspita, W., dkk. (2018). The Effect of Pindan Gonnung Traditional Game Toward Cognitive and Rough Motoric Development in Kindergarten. https://doi.org/10.2991/icei-18.2018.19

Santrock, John W. (2012). Life-Span Development. Terjemah Widyasinta Benedictine. Erlangga

Soetjiningsih. (2012). Perkembangan Anak dan Permasalahannya dalam Buku Ajar I Ilmu Perkembangan Anak dan Remaja. Jakarta: Sugengseto.

Sugiyono. (2016). Metode Penelitian Kuantitatif Kualitatif dan R\&D. Bandung: Alfabeta.

Sulyandari, Ari Kusuma. (2020). Pengembangan Sirkuit Bongkar Pasang untuk Aktivitas Fisik Motorik Kasar di Lembaga Prasekolah dengan Lahan Minimalis. Jurnal Seling: Jurnal Program studi PGRA. 6(2). (online) http://jurnal.stitnualhikmah. ac.id/index.php/seling/article/view/633 